Vol. 16 No. 1 - April 2016

\title{
The Contrastive and Contextual Analysis of the Verb Run
}

\author{
Arina Isti'anah \\ English Letters Department, Sanata Dharma University, Yogyakarta. \\ arina@usd.ac.id
}

\begin{abstract}
Words become the source for understanding the meanings of language. In relation to the study of meanings, this paper attempts at presenting the contrastive and contextual analysis of the verb RUN. The contrastive analysis is conducted in order to find the distinctive features of the word RUN and its synonymous words. After finding out the features differentiating the verb RUN, the contextual analysis is conducted. The contextual analysis displays the features which take place in the verb RUN in various fields. Based on the analysis, RUN has features of "manner", "agent", "situation", "distance" or "duration", "direction" and "purpose". The feature AGENT dominates the feature of RUN in the contexts which equals 28\%. The context of initiating the action causes the appearance of the feature AGENT. The feature distance or duration appears the least in the context of regular activity. The occurrence of the same feature in different contexts proves that a word shares the same feature in the different context, in other words, overlapping features happens.
\end{abstract}

Key words: semantics, contrastive, contextual

\section{Introduction}

Language cannot be separated from human beings since it connects people. By language, people can direct the ideas in their mind. Language consists of its elements due to its primary function in communication. The elements found in a language are sounds, words, phrases, clauses, sentences and texts. Its element in the language is not a simple one because it contains the rules which are quite complex. As the example, in studying the sound of language, the processes how the sounds are produced, what speech organs involved are also observed. The study of words is also prominent in language study. It involves the properties of how the words are composed and related to others. When words come to the real context, the meaning of the words will be more obvious.

This paper attempts at analyzing the contrastive and contextual analysis of the verb run. By doing the analysis, it is expected that the readers of this paper can see how a word has various features and meanings. Therefore, their knowledge in language will improve. This paper also presents the meanings of the verb run in the real context, meaning that the verb is taken from various fields. However, before going to the analysis, the theories of semantics, componential, contrastive and contextual analysis are elaborated so that the core of the analysis can be absorbed better. The theory of semantics becomes the background why this paper is worth studying. The understanding of componential and contrastive analysis illustrates how a word is composed by its features. The contextual analysis understanding shows how a context can enact the different meaning, but is possible to have the same features.

\section{Semantics}

Words are found in the dictionary so that it becomes the source to find the meanings. However, human beings are also capable to describe the meanings of words since human 
beings are the language users. Fromkin (2000) says, "To understand a language we need to know the meaning of words and the morphemes that compose them (151)." Therefore, words are the element of a language which cannot be denied. Words enable things and ideas to define. Furthermore, Fromkin (2000) says that we also must know how the meanings of words combine into phrase and sentence meanings. Finally we must interpret the meaning of utterances in the context in which they are made (151). Based on that statement, the knowledge of word meanings are the foundation in interpreting meanings in the greater contexts. Therefore, the analysis of the contrastive and contextual analysis of run is fruitful.

Finch (2005) argues that semantics deals with the ways in which words acquire meanings (136). Words are the tools to describe meanings, even though in certain case contexts are also important in order to describe the meanings. Semantics can be concluded as the study of the linguistic meaning of morphemes, words, phrases, and sentences. Many people assume that semantics only deals with meanings of words. However, there are some types of semantics as proposed by Fromkin, namely lexical semantics and phrasal or sentential semantics. Lexical semantics deals with the meanings of words and the meaning relationships among words. Phrasal or sentential semantics concerns with the meaning of syntactic units larger than words (152). People can find the meanings of words easily from the dictionaries. However, as suggested by Fromkin (2004), human beings are walking dictionaries because they know the meanings of thousands of words. Therefore, words meanings are part of one's linguistic competence. The term lexicon is the mental storehouse of information about words and morphemes (152).

\section{Componential Analysis}

The meanings of words have properties namely semantic properties. Fromkin (2004) argues that the presence of one semantic property can be inferred from the presence or absence of another (155). As the example is the word father. Some properties are found, such as "male", "mature", and "animate". Those features are necessary to define in order to find the distinctive meanings of the synonymous words. The features are also needed to conduct in order to find the same features of other words. When father is compared to boy, both of them have distinctive feature of "mature", and similarity in "male".

Siewierska in Katamba (2009) states that classical componential analysis involves comparing a set of words in a semantic field in pairs and distinguishing between them in terms of a set of binary features (195). A very simple example is below.

$$
\begin{array}{ll}
\text { man } & :+ \text { male, +mature } \\
\text { woman } & : \text {-male, +mature } \\
\text { boy } & : \text { +male, -mature } \\
\text { girl } & : \text {-male, -mature }
\end{array}
$$

The componential analysis above shows how words share the distinctive features. Binary features can be applied well in such words. The analysis above obviously shows how a word is composed by its feature in the sense of $/+/$ or $/-/$. However, in the synonymous words like run, catch, escape, and gallop will face difficulty if they are analyzed using binary features as above mentioned. Therefore, the contrastive analysis is needed.

\section{Contrastive Analysis}

Nida (1975) says that for the analysis of distinctive features or components of meaning, the relation of contiguity is decidedly the most important. It is said so because contiguity represents the relations between closely related meanings occupying a well-defined, restricted semantic domain, and exhibiting certain well-marked contrasts (18). Some synonymous words such as run, gallop, catch and escape have contrastive features. Even though the meaning seems the same, each word has different important feature which differentiate one another.

Each meaning is distinctly set off from other related meanings by at least one important feature (Nida, 1975:18). The 
words run, gallop, catch and escape constitute such a cluster of contiguous meanings. Those words have the same features in the angle of body movement, but different in the sense of purpose, for instance. However, the relation of contiguity does not apply to the words run, gallop, catch and escape. What can be applied are the meanings of those words which are related. It means that they share certain common features and constitute a single semantic domain.

Nida (1975: 32) clarifies that in examining and describing of the semantic components, to unite meanings as different senses of the same lexical unit and to separate them as distinct meanings are needed to involve. Therefore, the contrastive analysis is prominent. In the discussion part later, the contrastive analysis is conducted to the same lexical unit of the verb run. The features composing the verb run are also found.

\section{Contextual Analysis}

The obvious feature of the relation of meaning is the tendency for meanings to overlap (Nida, 1975:16). It cannot be denied that the meaning of a word only does not stand itself. When the same word occurs in the different context, the feature of the meaning also appears. Nida (1975: 138) suggests that in concerning the contextual meaning of the verb run, the classification and analysis are those which are nonidiomatic uses. Therefore, this paper only focuses on the contextual analysis of the verb run which does not constitute the idiomatic expression.

Some sources are involved in the contextual analysis of the verb run. The sentences are found in the academic articles, short stories, news and books. By involving various fields, the better understanding of the contextual analysis is expected to achieve. After presenting the contextual meanings of the verb run, finding out the feature of its context is conducted. By doing so, the percentage of features of the verb run in the context can be concluded. The percentage will show how the semantic feature overlaps in meanings.

\section{Discussion}

Nida (1975) says that one aspect of language which complicates the study of meaning is that even a single meaning of a term may include enormous range of referents, meanings objects to which such a form refer (13). The verb run may refer to quickly movement by legs. It may also be related to human or animals as the objects who do the activity. That illustration show how a word may create various referent, and therefore meanings. The following parts present and discuss the contrastive and contextual analysis of the verb run. Each part exhibits the table of either contrastive or contextual analysis of the verb run.

\section{Contrastive Analysis of Run}

In relation to the verb run, some words are assumed to have similar meanings. Even though the meanings are similar, there are some distinctive features which differentiate one word to another. Finding out the distinctive features of the verb run is important to conduct so that the readers can see how a word is composed by its features. The semantic features also differentiate the meanings even though two words are assumed as closely related. Table 1 below shows the distinctive features of the verb run and its synonymous words. 
Table 1. The Distinctive Features of the Verb run

\begin{tabular}{|c|c|c|c|c|c|c|c|}
\hline \multirow[b]{2}{*}{ No } & \multirow[b]{2}{*}{ Words } & \multicolumn{6}{|c|}{ Distinctive Features } \\
\hline & & Manner & Agent & Situation & $\begin{array}{c}\text { Distance } \\
\text { or } \\
\text { Duration }\end{array}$ & Direction & Purpose \\
\hline 1 & escape & $\begin{array}{l}\text { quickly, } \\
\text { careless }\end{array}$ & $\begin{array}{l}\text { human, } \\
\text { animal }\end{array}$ & $\begin{array}{l}\text { dangerous } \\
\text { situation }\end{array}$ & long & $\begin{array}{l}\text { from } \\
\text { somewhere }\end{array}$ & $\begin{array}{l}\text { to get out of } \\
\text { certain situation }\end{array}$ \\
\hline 2 & catch & quickly & $\begin{array}{l}\text { human \& } \\
\text { animal }\end{array}$ & sudden & short, long & in particular & $\begin{array}{l}\text { to get } \\
\text { something }\end{array}$ \\
\hline 3 & gallop & fast, quickly & horse & plain & long & $\begin{array}{l}\text { forward } \\
\text { movement }\end{array}$ & plain \\
\hline 4 & race & fast & human & $\begin{array}{l}\text { against } \\
\text { someone }\end{array}$ & long, short & particular & $\begin{array}{l}\text { sport, } \\
\text { competition }\end{array}$ \\
\hline 5 & rush & quickly & human & hurry & short & $\begin{array}{l}\text { go } \\
\text { somewhere }\end{array}$ & $\begin{array}{l}\text { go or do } \\
\text { something }\end{array}$ \\
\hline 6 & sprint & very fast & human & hurry & very short & particular & $\begin{array}{l}\text { sport, get } \\
\text { something }\end{array}$ \\
\hline 7 & jog & $\begin{array}{l}\text { slowly, } \\
\text { steadily }\end{array}$ & human & plain & short & somewhere & exercise \\
\hline 8 & scamper & quick & $\begin{array}{l}\text { child/ } \\
\text { animal }\end{array}$ & plain & very short & no particular & $\begin{array}{l}\text { playful, } \\
\text { frightened }\end{array}$ \\
\hline 9 & spurt & quickly & $\begin{array}{l}\text { human \& } \\
\text { animal }\end{array}$ & $\begin{array}{l}\text { start move, } \\
\text { regular step }\end{array}$ & short & $\begin{array}{l}\text { go } \\
\text { somewhere }\end{array}$ & plain \\
\hline 10 & trot & slowly & $\begin{array}{l}\text { horse, four } \\
\text { legs animal }\end{array}$ & regular step & short & $\begin{array}{l}\text { go } \\
\text { somewhere }\end{array}$ & plain \\
\hline 11 & tear & quick & human & $\begin{array}{l}\text { dangerous, } \\
\text { careless }\end{array}$ & long & $\begin{array}{l}\text { go } \\
\text { somewhere }\end{array}$ & drive \\
\hline
\end{tabular}

The table above shows that those synonymous words are distinctive in the angles of manner, agent, situation, distance, direction and purpose. Nida (1975) says that the meanings of words which share certain features with them but contrast with them in respect to other features (32). The situation of the word escape is in dangerous situation, whereas in the word catch the situation is sudden. In the sense of direction, escape derives from somewhere, while catch goes to particular direction. In the purpose feature, escape aims at getting out of certain situation, while catch aims at getting something. When those words are analyzed using componential analysis, it will be as follows.

$$
\begin{gathered}
\text { escape } \quad+\text { dangerous, + get out of } \\
\text { certain situation }
\end{gathered}
$$

\section{catch : - dangerous, - get out of certain situation}

However, the componential analysis of those two words is not determined as the most appropriate one. Since, the features found in the verbs escape and catch are various, therefore the contrastive analysis is seen as the best approach.

When the words escape and catch appear in the contexts as in

(1) He didn't attempt to touch her again, but he stood squarely in front of her, thwarting her attempts to escape

(2) We saw the eagle swoop from the sky to catch its prey,

the understanding of the semantic features which the words have can be done. The 
feature of "purpose" is seen obviously. Sentence (1) indicates that the feature "purpose" is to get out of something or certain situation. Whereas, sentence (2) indicates that the feature "purpose" is to get something.

The illustration above shares the idea that the meaning of synonymous words can be broken into several features. Finding out the features is important so that the understanding of the words can be fulfilled. As Nida (1975: 111) says that the semantic units share greatest number of common components and differ from another in the smallest number of diagnostic components. The contrastive features presented above exhibit how the small diagnostic components can differentiate the meaning of one word to another.

\section{Contextual Analysis of Run}

After analyzing the contrastive features occur in the word run and its synonymous words, it is necessary to find out the meanings of the word run in context. By conducting the contextual analysis, the overlapping feature occurs in the context can be seen obviously. The table below shows the contextual analysis of the verb run. Nida (1975) has defined the contextual analysis of the verb run. However, Nida does not provide the feature of the word in the context. Therefore, the table below is the improvement of Nida's analysis of the verb run.

Table 2. The Contextual Analysis of the Verb run by Nida (1975: 141-143)

\begin{tabular}{|c|l|l|l|}
\hline No & \multicolumn{1}{|c|}{ Contextual meaning } & \multicolumn{1}{|c|}{ Example } & Features \\
\hline 1 & $\begin{array}{l}\text { Movement in space through the } \\
\text { use of the limbs, and with } \\
\text { successive instances in which no } \\
\text { foot touches the ground }\end{array}$ & $\begin{array}{l}\text { He ran to the house } \\
\text { He ran the horse around the track } \\
\text { He scored a run in the third riding }\end{array}$ & Direction \\
\hline 2 & $\begin{array}{l}\text { Internal or movement of related } \\
\text { parts }\end{array}$ & $\begin{array}{l}\text { The motor is running } \\
\text { The clock is running fast }\end{array}$ & Manner \\
\hline 3 & Vehicular movement on schedule & $\begin{array}{l}\text { The train runs every hour } \\
\text { The ferry runs between Staten Island and the Battery }\end{array}$ & Manner \\
\hline 4 & Movement of a liquid or dry mass & $\begin{array}{l}\text { The water is running out of the faucet } \\
\text { The color is running }\end{array}$ & Situation \\
\hline 5 & Extension & $\begin{array}{l}\text { The grain of the wood runs crossways } \\
\text { He ran the strap around the box }\end{array}$ & Purpose \\
\hline 6 & General functioning & $\begin{array}{l}\text { The office runs well } \\
\text { He ran his business poorly }\end{array}$ & Manner \\
\hline 7 & $\begin{array}{l}\text { Continuous series of step like } \\
\text { actions }\end{array}$ & $\begin{array}{l}\text { Her stocking is running } \\
\text { She has a run in her silk hose }\end{array}$ & Purpose \\
\hline 8 & $\begin{array}{l}\text { Movement in space, not } \\
\text { necessarily as in no.l }\end{array}$ & $\begin{array}{l}\text { He built a chicken run } \\
\text { She runs with a touch crowd }\end{array}$ & Agent \\
\hline 9 & $\begin{array}{l}\text { Relating to election to office: He's running for election } \\
\text { Relating to publication: they ran the edition on an offset } \\
\text { press } \\
\text { Relating to financial operations: the run on the bank was } \\
\text { disastrous } \\
\text { Relating to contents: the minutes run as follows. } \\
\text { Possible figurative meanings: they run the blockade } \\
\text { Miscellaneous: the rope ran through a pulley. }\end{array}$ & Purpose \\
\hline & \begin{tabular}{l} 
accial \\
\hline
\end{tabular} & & \\
\hline
\end{tabular}

In Nida's analysis of the verb run, not all distinctive features appear. The occurrence of distance or duration is not seen in the feature column. Below is the summary of features of run in the context. 
Chart 1. Semantic Features found in the Context (Nida, 1975: 138)

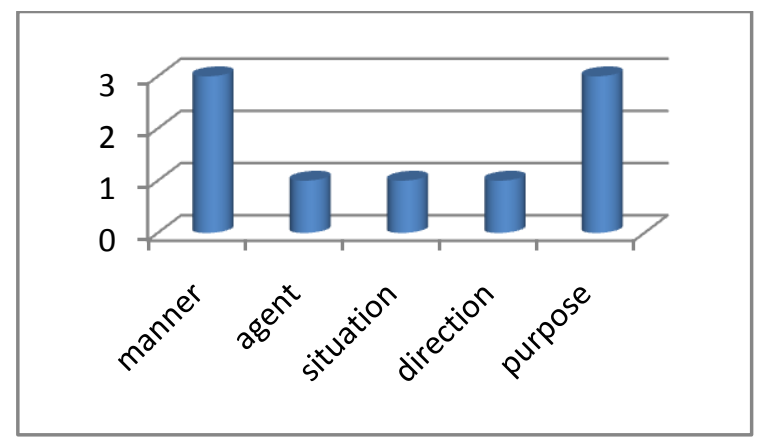

The chart above displays that Nida's contextual analysis of the verb run is dominated by the features of manner and purpose. However, what Nida's conducts is not complete yet. Therefore, the table below shows the contextual analysis of the verb run which is found in some fields such as short stories, news and articles.

Table 3. The Extended Contextual Analysis of the Verb run

\begin{tabular}{|c|c|c|c|c|}
\hline No & Context & Meaning & Example & Features \\
\hline 1 & Authority & $\begin{array}{l}\text { To control a } \\
\text { business }\end{array}$ & $\begin{array}{l}\text { Duncan and Avis McKelvie, who run the Puffin Dive School in } \\
\text { Oban, have a very sensible attitude towards diver training. }\end{array}$ & Agent \\
\hline 2 & Ability & To drive & $\begin{array}{l}\text { It is fully comprehensive and covers the mobility supplement } \\
\text { holder and two drivers nominated by the holder, so you don't } \\
\text { have to be a driver to run a Motability car }\end{array}$ & Agent \\
\hline 3 & Technology & To operate & $\begin{array}{l}\text { These are machines that run on IBM software and in other } \\
\text { ways appear similar to the equipment of the market leader. }\end{array}$ & Agent \\
\hline 4 & Urgent situation & To challenge & $\begin{array}{l}\text { But when they do arise, police and military planners are } \\
\text { caught on the horns of a dangerous dilemma: do they smash } \\
\text { in quickly and run the risk of death or injury? }\end{array}$ & Situation \\
\hline 5 & One's regret & $\begin{array}{l}\text { To be } \\
\text { responsible }\end{array}$ & He never thought I was fit to run a shoe shop. & Agent \\
\hline 6 & $\begin{array}{l}\text { Certain } \\
\text { situation }\end{array}$ & $\begin{array}{l}\text { To face a } \\
\text { problem }\end{array}$ & $\begin{array}{l}\text { Public enterprises run little risk of bankruptcy, and if targets } \\
\text { are not met, governments usually step in to cover deficits. }\end{array}$ & Situation \\
\hline 7 & Schedule & To take place & The event kicks off Tuesday and runs through Friday. & $\begin{array}{l}\text { Distance } \\
\text { or duration }\end{array}$ \\
\hline 8 & One's opinion & $\begin{array}{l}\text { To be } \\
\text { responsible of a } \\
\text { job }\end{array}$ & $\begin{array}{l}\text { "The platform he is going to run or announce on Wednesday } \\
\text { will tell us what his program is, but whether it's Sepp Blatter } \\
\text { or somebody else, I hope the president of FIFA understands } \\
\text { the massive image problem that FIFA has and has to go about } \\
\text { pro-actively fixing it," Murray told the newspaper in an } \\
\text { interview from Zurich. }\end{array}$ & Purpose \\
\hline 9 & Movement & To move quickly & $\begin{array}{l}\text { And will you excuse me if I run and jump and do } \\
\text { handsprings? }\end{array}$ & Manner \\
\hline 10 & $\begin{array}{l}\text { Certain } \\
\text { situation }\end{array}$ & $\begin{array}{l}\text { To continue a } \\
\text { process }\end{array}$ & We are running recovery operations. & Agent \\
\hline
\end{tabular}




\begin{tabular}{|c|c|c|c|c|}
\hline 11 & $\begin{array}{l}\text { Computer } \\
\text { program }\end{array}$ & To perform & $\begin{array}{l}\text { There are a lot of activities on the web. Live streaming of the } \\
\text { rallies are carried on Internet channels manned by } \\
\text { mainstream media companies, while political sites such as } \\
\text { The Online Citizen (TOC) run live commentaries of the rallies } \\
\text { throughout the night. }\end{array}$ & Manner \\
\hline 12 & $\begin{array}{l}\text { Buses' } \\
\text { movement }\end{array}$ & To operate & On both corridors, Transjakarta buses run until 11:30 p.m. & $\begin{array}{l}\text { Distance or } \\
\text { duration }\end{array}$ \\
\hline 13 & Law policy & To occur & $\begin{array}{l}\text { The amnesty will run throughout June, July and August, the } \\
\text { trust said. }\end{array}$ & $\begin{array}{l}\text { Distance or } \\
\text { duration }\end{array}$ \\
\hline 14 & Business & $\begin{array}{l}\text { To face a } \\
\text { situation }\end{array}$ & $\begin{array}{l}\text { "The problem is in a normal business, if you run into trading } \\
\text { difficulties, you can circle the wagons, you can close some } \\
\text { branches that are not profitable, you can get rid of staff and } \\
\text { just generally cut the overheads," he said. }\end{array}$ & Situation \\
\hline 15 & Fiction & To open & Together they run a cafe for a varied fairytale clientele. & Agent \\
\hline 16 & Adventure & $\begin{array}{l}\text { To move in the } \\
\text { lower place }\end{array}$ & $\begin{array}{l}\text { HESTER bade little Pearl run down to the margin of the water, } \\
\text { and play with the shells and tangled sea-weed, until she } \\
\text { should have talked awhile with yonder gatherer of herbs. }\end{array}$ & Manner \\
\hline 17 & Playful & To start & $\begin{array}{l}\text { Forth peeped at her, out of the pool, with dark, glistening } \\
\text { curls around her head, and an elf-smile in her eyes, the image } \\
\text { of a little maid, whom Pearl, having no other playmate, } \\
\text { invited to take her hand and run a race with her. }\end{array}$ & Purpose \\
\hline 18 & One's decision & To leave a belief & $\begin{array}{l}\text { Certainly my conscience will serve me to run from this Jew } \\
\text { my master. }\end{array}$ & Direction \\
\hline 19 & Mystic & $\begin{array}{l}\text { To ask someone } \\
\text { to move }\end{array}$ & $\begin{array}{l}\text { The fiend is at mine elbow, and tempts me, saying to me, } \\
\text { 'Gobbo, Launcelot Gobbo, good Launcelot,' or 'good Gobbo,' or } \\
\text { 'good Launcelot Gobbo, use your legs, take the start, run } \\
\text { away.' }\end{array}$ & Direction \\
\hline 20 & Belief & To find a faith & Run to my Lord of Suffolk; let him know & Purpose \\
\hline 21 & $\begin{array}{l}\text { Body } \\
\text { interaction }\end{array}$ & $\begin{array}{l}\text { To leave } \\
\text { someone }\end{array}$ & $\begin{array}{l}\text { Chignell tightened his grip on her arm as though he expected } \\
\text { her to run away }\end{array}$ & Purpose \\
\hline 22 & Performance & To play & This film will run and run & Manner \\
\hline 23 & Exhibition & To hold & I just run local affairs for a dozen or so missions & Agent \\
\hline 24 & Physics & To move & $\begin{array}{l}\text { Planet } X \text { will also run on Apple Quadras now and support } \\
\text { Apple monochrome displays }\end{array}$ & Direction \\
\hline 25 & Politics & $\begin{array}{l}\text { To move from a } \\
\text { place }\end{array}$ & $\begin{array}{l}\text { We are told that unless we make peace with these noblemen, } \\
\text { candidates are to be run all over the country }\end{array}$ & Direction \\
\hline 26 & Film & To display & $\begin{array}{l}\text { At first, the two parts of the film are simply run in parallel, } \\
\text { not fully joined, in a form known as a 'double-head' }\end{array}$ & Manner \\
\hline 27 & Politics & To take place & $\begin{array}{l}\text { Yet, one of the catchwords that has been widely heard in } \\
\text { Washington and elsewhere during the run up to the war has } \\
\text { been the need to create a democratic environment in the } \\
\text { Middle East after the war is over. }\end{array}$ & Situation \\
\hline 28 & Education & To be controlled & $\begin{array}{l}\text { Run by the Open College of the Arts in association with the } \\
\text { Trust, 'The Art of Garden Design' aims to introduce the } \\
\text { principles of good, small-scale garden planning through a } \\
\text { series of practical activities. }\end{array}$ & Agent \\
\hline 29 & $\begin{array}{l}\text { Habit in the } \\
\text { past }\end{array}$ & To move & And they used to run from here to Har wich & Situation \\
\hline 30 & Ability & To control & $\begin{array}{l}\text { One such black hole could run ten large power stations, if } \\
\text { only we could harness its power. }\end{array}$ & Agent \\
\hline
\end{tabular}




\begin{tabular}{|c|c|c|c|c|}
\hline 31 & Computer & To operate & $\begin{array}{l}\text { You need DOS version } 2.0 \text { or higher, with } 512 \mathrm{~Kb} \text { of RAM and } \\
\text { an IBM compatible computer to run the program. }\end{array}$ & Purpose \\
\hline 32 & Company & To make & $\begin{array}{l}\text { Since SCOTVEC personnel could not respond to requests from } \\
\text { all centers to run staff development events for them, each } \\
\text { workshop was developed as a pack of information, examples } \\
\text { and activities for participants together with extensive support } \\
\text { material so that centres or Regions can themselves organise } \\
\text { and run the events. }\end{array}$ & Purpose \\
\hline 33 & Exhibition & To take place & $\begin{array}{l}\text { 'The Power of the Mask' will run from August to the end of } \\
\text { October this year and there will be lots of associated events } \\
\text { and activities. }\end{array}$ & $\begin{array}{l}\text { Distance or } \\
\text { duration }\end{array}$ \\
\hline 34 & Rules & To use & $\begin{array}{l}\text { Bearing in mind the number of private nursing homes that } \\
\text { spring up and erm, er, I mean the sort of privately run places } \\
\text { er, presumably the local authorities have to give them a } \\
\text { license to run, but is there no way that it, can the Fire } \\
\text { Service, can our officers go and make an inspection? }\end{array}$ & Purpose \\
\hline 35 & Dangerous & $\begin{array}{l}\text { To get out of a } \\
\text { place }\end{array}$ & $\begin{array}{l}\text { She struggled not to run screaming from the office, seeing } \\
\text { the trip ahead, knowing what would happen, that desire, that } \\
\text { overpowering excitement flaring up between them in a hotel } \\
\text { bedroom somewhere on the other side of the world, dragging } \\
\text { her deeper into a relationship that was already tearing her to } \\
\text { pieces. }\end{array}$ & Direction \\
\hline 36 & $\begin{array}{l}\text { Finding out a } \\
\text { place }\end{array}$ & To reach & $\begin{array}{l}\text { Meanwhile back on the ward, Doctor Beri's bleep goes } \\
\text { again... this time it's a call to casualty... and the weary } \\
\text { house physician has to run half a mile from one end of the } \\
\text { building to the other... along the new corridor linking the old } \\
\text { part of the hospital with the new. }\end{array}$ & Purpose \\
\hline 37 & Sport & To move & $\begin{array}{l}\text { Both England stars started their careers at Acklam Park, } \\
\text { Middlesbrough, and youngsters, aged nine to } 14 \text {, can now } \\
\text { learn to run with the ball and line up for line-outs with the } \\
\text { Rugby Union course on the same turf. }\end{array}$ & Manner \\
\hline 38 & Competition & To play & $\begin{array}{l}\text { Hateley was one of several players banned from Ibrox until } \\
\text { yesterday in the wake of last Saturday's defeat from Celtic } \\
\text { that brought to an end Rangers' run of } 44 \text { games without } \\
\text { loss. }\end{array}$ & Agent \\
\hline 39 & Sport & To leave a place & $\begin{array}{l}\text { Latham and Andrew Jones put on } 127 \text { for the second wicket } \\
\text { before the opener was run out when his partner failed to } \\
\text { respond to a call for a run. }\end{array}$ & Direction \\
\hline 40 & Business & $\begin{array}{l}\text { To control a } \\
\text { business }\end{array}$ & $\begin{array}{l}\text { It is not a simple case that we can run along, sell a few } \\
\text { houses, get the capital receipts and suddenly we can go off } \\
\text { and have a wonderful program and replace the assets which } \\
\text { we have sold and... }\end{array}$ & Agent \\
\hline
\end{tabular}

The features which occur in the contextual analysis above can be summarized in the chart below. The numbers presented below correspond in percentage (\%). 
Chart 2. Semantic Features found in the Context (Extended)

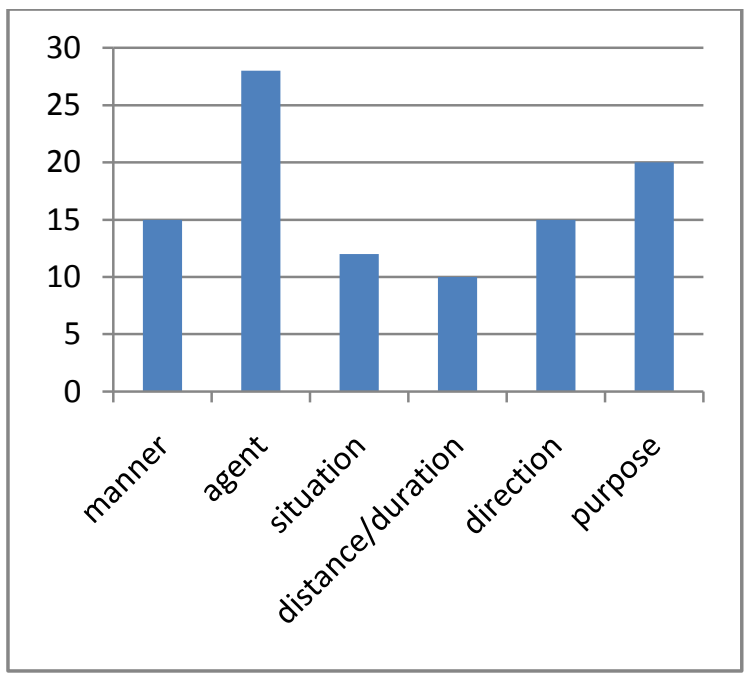

The table above shows that "agent" appears most as the semantic feature of run found in the context. "Agent" appears as 28\%. After "agent", "purpose" is the next feature which equals $20 \%$ in the context of run. "Manner" and "direction" have the same percentage, $15 \%$. "Situation" is the feature which is found as $12 \%$. The last feature which appears the least is "distance" or "duration" which equals $10 \%$. Table 3 above displays that the same features can appear in different contexts.

The contextual meanings of a word cannot be separated from the contrastive features. Each context represents the feature of the word has. The feature characterizes the meaning since different feature can also define a new meaning. In the examples no.1 and 4, run has "agent" and "situation" as the contrastive features. Run in no.1 means to control a business in the context of authority. Whereas, run in no.4 means to challenge a risk in the context of urgent situation. In meaning no.1, "agent" is assumed as the feature since to control a business needs an "agent". In other words, "agent" is the feature which characterizes the act of running. In meaning no. 4 which means to challenge a risk, "situation" is argued as the features which corresponds the meaning. Run can mean to challenge when the typical context underlying the feature is "situation". We cannot substitute the feature "agent" in the meaning no.4 because it will change the meaning.

The same contrastive feature may also appear in different context. The example is found in meanings no. 2 and 3. Both share the same contrastive feature, "agent". However, the meanings are different. The meaning of no. 2 is to drive, while no. 3 is to operate. It is because of the different context the verb run takes place. The context in no. 2 is ability and no. 3 is technology. The "agent" is concluded as the feature representing the meaning due to the fact that both contexts need the "agent" to construct the meaning. The "agent" in no. 2 is animate, a human who is able to drive. Whereas, the "agent" in no. 3 is inanimate, meaning a machine which is able to operate. It can be assumed that even though the same feature appears in the different contexts, the meanings of a word will be distinctive. Therefore, we can say that context may determine the distinctive meaning of a word.

In meanings no. 30 and 40 , they share the same feature, "agent". The context is different because meaning no. 30 has ability and no.40 has business as the contexts. However, they have the same meaning, to control. Sentence no.30 is said as having ability context due to the fact that it is because of the "agent's" ability. The meaning to control refers to what the "agent" does as the ability which marks the context. Sentence no.40 has business as the context since the meaning to control refers to business which the "agent" rules. Therefore, the similar meaning may appear in the different context when they share the same feature.

The different context with the same feature can also create the similar meaning. This situation can be found in meaning no. 35 and 39. The context of meaning no.35 is dangerous and context no.39 is sport. They share the same feature, "direction". It is chosen as the feature because the meaning is to leave or get out of a place. The context dangerous in meaning no.35 initiates the agent to get out of a place. "Agent" is not assumed as the feature since it does not mark the meaning. Since the meaning is to get out of a place in dangerous situation, therefore "direction" is seen as the appropriate feature. The similar meaning occurs in sentence no.39 
even though the context is different. The context of meaning no.39 is sport since the circumstance triggering the agent to move. It also explains that meaning can be similar in the different context. However, the semantic feature which corresponds the word also influence the definition of the word being analyzed.

Nida (1975: 141) already presents the contextual meaning of the verb run. The meanings presented by Nida also overlap with the meanings displayed in table.4. As the example, Nida defines that run can mean vehicular movement on schedule which has "manner" as the feature. The example of sentence is found in table 3, no.2. In table 3, no.7, we can also find the context of schedule. The feature is "direction" or "duration". The meaning is also different because in meaning no.7, run means to take place in particular schedule. Even though the features shared by no. 2 and no. 4 are different; people can see the similarities in the occurrence of run which is scheduled.

\section{Conclusion}

The meanings of the verb run can be derived from its features and contexts. The same context can cause the different meaning even though the features are also the same. The similar meanings can come from the different context and features depending on what core are marked. The same features do not guarantee the same meanings since the context also takes an important role in finding out the meaning. The overlapping features is found in the contexts due to the fact that the verb run has some features. Based on the analysis, the verb run has semantic features of "manner", "agent", "situation", "distance" or "duration", "direction", and "purpose". When the verb run occurs in various contexts, the features also appear. In the context, "agent" is the most feature which appears, 28\%. "Purpose" is the next feature found in the context, $20 \%$. The semantic feature "manner" and "direction" have the equal percentage in the context, 15\%. "Situation" and "distance" or "duration" appear as the last two features of the verb run in the context which equal $12 \%$ and $10 \%$. It can be summed up that a word is composed by its features. When a word takes place in various contexts, the feature composing the word is also found.

\section{References}

Curse, D. Alan. Meaning in Language: An Introduction to Semantics and Pragmatics. New York: Oxford University Press, 2000.

Finch, Geoffrey. Key Concepts in Language and Linguistics. New York: Palgrave Macmillan, 2005.

Fromkin, Victoria A. An Introduction to Language $4^{\text {th }}$ edition. Victoria: South wood Press Pty Ltd., 2000.

Katamba, Francis et al. English Language: Description, Variation and Context. New York: Palgrave Macmillan, 2009.

Nida, Eugene. Componential Analysis of Meaning: An Introduction to Semantic Structures. Mouton: The Hague, 1975. 